\title{
Thinking with Animals in Upper Palaeolithic Rock Art
}

\author{
Georges Sauvet, Robert Layton, Tilman Lenssen-Erz, \\ Paul Taçon \& André Wlodarczyk
}

\begin{abstract}
This article develops a novel method for assessing the cultural context of rock art, and applies it to the rock art of the Upper Palaeolithic of France and Spain. The article relies on a generative approach, assuming that artists have the potential to choose which motifs to select from the repertoire or vocabulary of their artistic system, but that appropriate choices at any place are guided by the location of that site within the culturally-mediated geography of the region. Ethnographic studies of rock art depicting animal species produced in the contexts of totemism, shamanism and everyday life are used as reference points in

an analytical framework, which is then applied to a number of ancient traditions.
\end{abstract}

\section{Background to the article}

\section{Introduction}

In a review article published in Cambridge Archaeological Journal (2000), Layton argued that interpretations of Upper Palaeolithic rock art based on shamanism had come to dominate the field, displacing viable alternative hypotheses. Layton proposed that the art of shamanism was merely one way of appropriating motifs from the artistic vocabulary of a cultural system and outlined a method for discriminating between the distinctive ways in which totemic, shamanic and secular rock art draw on such a vocabulary through the choice of which motifs to represent, both at individual sites and across a wider region. The present article tests this method using more extensive data and improved statistical methods. The results of the test are presented, and the validity of the method subjected to critical assessment.

Few existing archaeological studies of rock art develop a method where a range of alternative hypotheses can be given equal weight; most tend to act as advocates for one preferred interpretation, but we believe that the method described here is capable of further refinement and wider application. A similar method to ours was used by Tilley (1991) to compare the statistical frequency of motifs on panels at the prehistoric Namforsen site complex and other Scandinavian sites of the same period. Tilley, however, found that all sites in his survey are essentially similar and he did not use ethnographic case studies of motif distribution as a baseline. Hartley's (1992) analysis of motif frequencies in the rock art of the Colorado Plateau was more successful. Hartley found that there was a greater diversity of art motifs on isolated boulders than in rock shelters. He argued (drawing on local and comparative ethnography) that the difference probably arose through prolonged use of rock shelters by the same or related groups, while isolated boulders were probably visited by members of more diverse local groups. A similar method is used here to locate Upper Palaeolithic Europe in a field of ethnographically defined cultural variation. Like Hartley $(1992,64)$, we are not seeking to construe the meaning of individual motifs, but rather the cognitive structures of which the use of motifs is symptomatic. By 'cultural context' we therefore mean the relationship between aspects of behaviour, material culture and the system of ideas characteristic of a particular community. A high proportion of the identifiable figures in the Upper Palaeolithic art of France and Spain are animals. Following Lévi-Strauss's (1962, 89) dictum that 'animals are good to think with', we analyse the cultural context of animal figures in various recent rock-art traditions and ask what light this can throw on the cultural context of the animal art of the Upper Palaeolithic.

Almost as soon as archaeologists realized that the Upper Palaeolithic rock art of southwest France 
had been created by prehistoric hunter-gatherers, they began to search for a key to its cultural significance in the art of modern hunter-gatherers. As early as 1903 Reinach argued that living hunter-fisher societies could provide better parallels with the societies of the 'Age of the Reindeer' than could medieval French culture. Two possible parallels have dominated the literature: Reinach's preferred parallel with totemism and the now more familiar parallel with shamanism.

\section{Totemism}

The word totem comes from the Ojibwa, a native North American people, while the word shaman comes from the Tungus of central Siberia. Their use cross-culturally, to refer to types of religion (i.e. shamanism and totemism), is an artefact of anthropology. The validity of totemism as a cross-culturally valid category has been vigorously debated in anthropology (see LéviStrauss 1962 for an authoritative review). It is generally agreed to refer to the use of animals or plants as emblems or guardians of social groups celebrated in ritual. The rationale of totemism is that each group is identified with a different species; the significance of each species derives from its place in the cognitive structure. Group A is kangaroo because it is not emu or python (see Lévi-Strauss 1964, ch. 5). Hartley's (1992) analysis of Colorado rock art relied on ethnographic evidence for clan totemism in the American Southwest to predict the consequences of the long-term accumulation of motifs at different sites.

Reinach (1903) rejected the initial 'Art for Art's Sake' hypothesis that Upper Palaeolithic cave art was a mere leisure-time amusement on the grounds that only certain species (food animals but not dangerous ones) were represented in the caves of southwest France, and because the paintings were placed far from the cave entrance, in places that were difficult to reach. He found the central Australian ethnography of Spencer \& Gillen (1899) particularly enlightening. The Upper Palaeolithic is dominated by paintings and engravings of animal species. Central Australian rituals are designed to increase numbers of each clan's totemic species, both through rock paintings representing the totem and through dances imitating the animal's behaviour. Reinach assumed that only desirable food animals would be the object of increase rites. Most of the central Australian painted sites are, moreover, in locations that women, children and uninitiated men are forbidden from entering, suggesting a parallel with the location of surviving French cave art. Reinach (1903, 261-2) appreciated that although 'all have the sole goal of increasing the number of the animals or plants after which their totem is named', nonetheless 'each [clan] totem has a special ceremony, and no two ceremonies are alike'. He did not, however, follow this observation to its logical conclusion by asking whether each French cave was characterized by paintings of a particular species, the putative totem of a local clan.

\section{Shamanism}

Shamanism refers to the use of spirits as guardians and helpers of individuals, contacted through trance to effect healing. The cross-cultural validity of the term shamanism has been considered by Eliade (1972), Hultkrantz (1989), Lewis (1971) and Vitebsky (1995). These authors do not agree on whether all known cases of shamanism have a common origin, or whether different traditions of healing during spirit possession arose independently. Beaune (1998) notes that shamanism has been proposed more than once as a context for the production of Upper Palaeolithic art. In their monograph on Altamira, Cartailhac \& Breuil (1906) compared some engravings to the animal masks worn by Inuit shamans. Beaune argues that shamanism nonetheless made little contribution to the repertoire of ethnographic parallels during the era dominated by Breuil, because most of the ethnographic literature was published in Russian. Shamanism assumed more importance during the 1950s-60s, particularly in the work of Kirchner (1952) and Kuhn (1956). Parallels were drawn between the antler-bearing 'sorcerer' of Les Trois Frères and the costumes of Siberian shamans, while Kuhn (1956, 37-8), citing Kirchner, added a second example, comparing the apparently bird-headed human figure in the Lascaux 'Pit Scene' to a Siberian shaman falling into trance.

Lewis-Williams's revival of the shamanic interpretation of Upper Palaeolithic art (Lewis-Williams \& Dowson 1988; Clottes \& Lewis-Williams 1996) was inspired by his previous work on the rock art of the Drakensberg Mountains in South Africa. In his early work, Lewis-Williams (1981) used the nineteenth- and twentieth-century ethnography of hunter-gatherers in southern Africa to interpret the art of the Drakensberg as an expression of local Maluti San religion. LewisWilliams's interpretations were convincing because he was able to match rituals recorded in other San ethnographies with detailed scenes in the rock art, and because the special, spiritual relationship between humans and eland suggested in the fragmentary ethnography of the Drakensberg provided by Qing, survivor of a massacre, corresponded to the high frequency of eland (60 per cent of animal figures) in the Drakensberg rock art recorded by Vinnicombe $(1975,364)$. Lewis-Williams did not use the term 'shaman' in this work, but he did devote one chapter to 
'The medicine man and the eland', where he argued that when 'medicine men' went into trance during curing rituals they identified themselves with the eland. Lewis-Williams cites Bleek's well-regarded nineteenth century ethnography of the /Xam San of the Strandberg-Katkop region, which described men wearing gemsbok scalps when performing curing rituals (Bleek 1935; 1936; cited in Lewis-Williams 1981; see Barnard 1992, 79, 82 for an assessment of Bleek's work; the /Xam are now, in Barnard's words 'culturally and linguistically extinct' $(1992,12))$. Lewis-Williams (1981) interpreted representations of composite elandhuman figures in Drakensberg art as depictions of trance experience.

Parallel research was carried out by Whitley (1994) on the rock art of the last 1500 years in the Coso Ranges in eastern California. Fifty-one per cent of engravings in the Coso Ranges depict mountain sheep, followed by 29 per cent made up of various geometric patterns (Whitley 1994, 360). Whitley rejects earlier archaeologists' hunting magic explanations on the grounds that fewer mountain sheep were hunted during this period than earlier ones, and there is no ethnographic record of hunting magic. Rather, the ethnography associates mountain sheep with shamanic rituals.

Although the relative frequency of culturally significant animal species played an important evidentiary role in both these studies, Lewis-Williams \& Dowson (1988) proposed an alternative line of evidence for shamanism in the Upper Palaeolithic, namely the similarity in shape between some of the Palaeolithic signs and forms that neuropsychologists had identified as characteristically perceived during altered states of consciousness. There is no ethnographic evidence from southern Africa that geometric figures depict shapes seen during trance (LewisWilliams \& Dowson 1988, 205). The evidence advanced was of formal similarity between the geometric forms seen in the rock art of the Drakensberg and Coso, psychological studies of drug-induced states of altered consciousness, and Reichel-Dolmatoff's (1978) ethnographic study of Tukano art, in which the Tukano themselves identify forms seen during the first phase of drug-induced trance. Numerous criticisms have been made of this argument, of which the most forceful is Helvenston \& Bahn (2005).

We therefore advocate a closer look at patterning in the distribution of the animal motifs that have been appealed to repeatedly as evidence for the cultural context of Upper Palaeolithic art, and which play an important role in all the ethnographic cases cited as possible parallels.
The theoretical framework

The approach taken in this article is based on a generative model. In any situation, artists have the potential to choose which motifs to select from the repertoire or vocabulary of their artistic system. The appropriate choice will be dictated by the context, in this case, the location of the site within the culturally mediated geography of the region. Painters and engravers are motivated by considerations of appropriate subject and context. If these motivations remain constant for long enough, a visible, archaeologically-measurable pattern will be generated.

Ethnographic cases frequently demonstrate that more than one cultural theme is expressed through a community's rock art, but these are typically differentiated by the size or style of figures. The analysis carried out below is concerned only with the distribution of animal motifs. In the final section of the article, we consider the potential effect that the co-presence of more than one cultural theme (e.g. totemism and sorcery) may have on the distribution of animal motifs. We do not analyse the distribution of anthropomorphs, which are very common in some traditions such as the rock art of the Australian Kimberleys, but rare in the art of the European Upper Palaeolithic and, for example, the recent art of Western Arnhem Land. The discernable motifs of the Upper Palaeolithic are predominantly of two classes: animals and 'signs'. Signs are quite possibly non-representational, and may express a different aspect of the culture, but a rather large number of animal species can be distinguished by body shape. A number of recent huntergatherer rock-art traditions are also characterized by a large number of recognizable animal species (often between 15 and 25 species), whereas the iconography of anthropomorphs is more opaque and dependent on cultural convention. The distribution patterns seen in the location of animal motifs therefore provides a useful means for comparative analysis that is particularly pertinent to the Upper Palaeolithic.

In order to test the method, we take the three hypotheses for the context of Upper Palaeolithic art outlined above (Art for Art's Sake, Totemism and Shamanism) as our starting point, and explore how closely the distribution of animal species in the Upper Palaeolithic conforms to the pattern seen in ethnographic cases where data on species frequency within and between sites are available. Although the 'Art for Art's sake' interpretation was quickly rejected by Upper Palaeolithic archaeologists, we consider that it should not be dismissed out of hand. There are several ethnographic cases of secular art from Australia. In an unpublished report on coastal Cape 


\begin{tabular}{|c|c|c|}
\cline { 2 - 3 } \multicolumn{1}{c|}{} & \multicolumn{2}{|c|}{ Distribution } \\
\hline Frequency & $\begin{array}{c}\text { Each motif only appears in } \\
\text { certain sites }\end{array}$ & $\begin{array}{c}\text { The same motifs are present in } \\
\text { nearly all sites }\end{array}$ \\
\hline $\begin{array}{c}\text { Certain motifs are present at least } \\
\text { twice as frequently as the mean } \\
\text { for other motifs }\end{array}$ & Shamanic $[\mathrm{C}]$ \\
\hline $\begin{array}{c}\text { All motifs have low or } \\
\text { similar frequencies }\end{array}$ & Totemic $[\mathrm{A}]$ & Secular $[\mathrm{B}]$ \\
\hline
\end{tabular}

Figure 1. Differentiation of rock-art traditions by motif frequency.

York, North Queensland, John and Leslie Haviland report that they were told by local Aboriginal people that the great majority of rock paintings they saw were 'the result of lengthy stays in the caves during the rainy season ... a sort of rainy day pastime' (quoted in Layton 1995, 222). David Turner spoke to Balrumba, a living artist who had painted in shelters on Bickerton Island in the Gulf of Carpentaria. Balrumba identified paintings as records of successful hunts, the visit of a European ship from which men had bought tobacco and so forth (Turner 1973). Men in Eastern Arnhem Land described paintings in wet-season rock shelters as records of foraging expeditions 'to make the cave look good', or to show others there was plenty of food in the area (Layton 1992, 74). 'Art for Art's Sake' corresponds to what we call secular or quotidian art in the following paragraphs.

Sympathetic magic is not a category of the same order as those we consider. Magic seemed a plausible motive for prehistoric rock art to early researchers because it was identified as the first step in the three-phase theory of human cognitive evolution proposed by J.G. Frazer in The Golden Bough (first published 1890), where magic precedes religion, which is followed by science. There are three compelling reasons for abandoning this interpretation. Many ethnographic cases of 'sympathetic magic', such as Aboriginal increase rites, or shamans dreaming of hunting success (York et al. 1993, 70-71, 136), are embedded within the local religion. Contrary to Frazer's understanding, sympathetic magic is often not believed to take effect automatically, but to rely on the intervention of spiritual agencies. Second, much of the evidence for supposedly wounded animals in Upper Palaeolithic art is ambiguous (see, for example, Bahn 1991). Thirdly, it is impossible, without ethnographic information, to tell whether a painting or engraving of a speared animal depicts a wished-for outcome, or a successful hunt. As the Aboriginal artist Namandijaugwa explained to David Turner (1973), ‘Nawanna killed it [a porpoise] and I saw it and painted it'. Ken Mulvaney gives another example (Mulvaney 1996, 11). We therefore exclude sympathetic magic, as a category, from our analysis.

Layton (2000) represented the three alternative hypotheses as a simple four-cell matrix, based on two axes: the frequency of particular motifs within the assemblage at individual sites, and their relative frequency across the region occupied by a huntergatherer community (Fig. 1). In regions where the animal art is an aspect of totemism the number of species represented is high, but most are depicted at a small proportion of sites, since each belongs to a particular clan. Consequently, the frequency of each motif in the total sample is low, and the number of sites at which it appears is small. On the other hand where rock art is associated with shamanism, if the cases described by Lewis-Williams and Whitley are representative, a small number of animal species will predominate both at individual sites and across the whole region. Secular art represents a kind of null hypothesis that no species has any special significance for anyone. All sites in the region have the same characteristics, such that all motifs are depicted with roughly equal frequency (as in totemism), but every one occurs at all or most sites (as in shamanism). These different situations are represented in the matrix. Note that the empty cell represents a permutation for which we lacked empirical evidence. It also seemed unlikely that certain motifs could occur at least twice as often as others in the region yet only appear at a small proportion of sites.

\section{Testing the model}

\section{A preliminary survey}

Layton (2000) compared a sample from the Upper Palaeolithic with three ethnographic cases representing the three principal interpretations based on ethnographic analogy advanced for the Palaeolithic. The Western Kimberley of Australia was taken as 


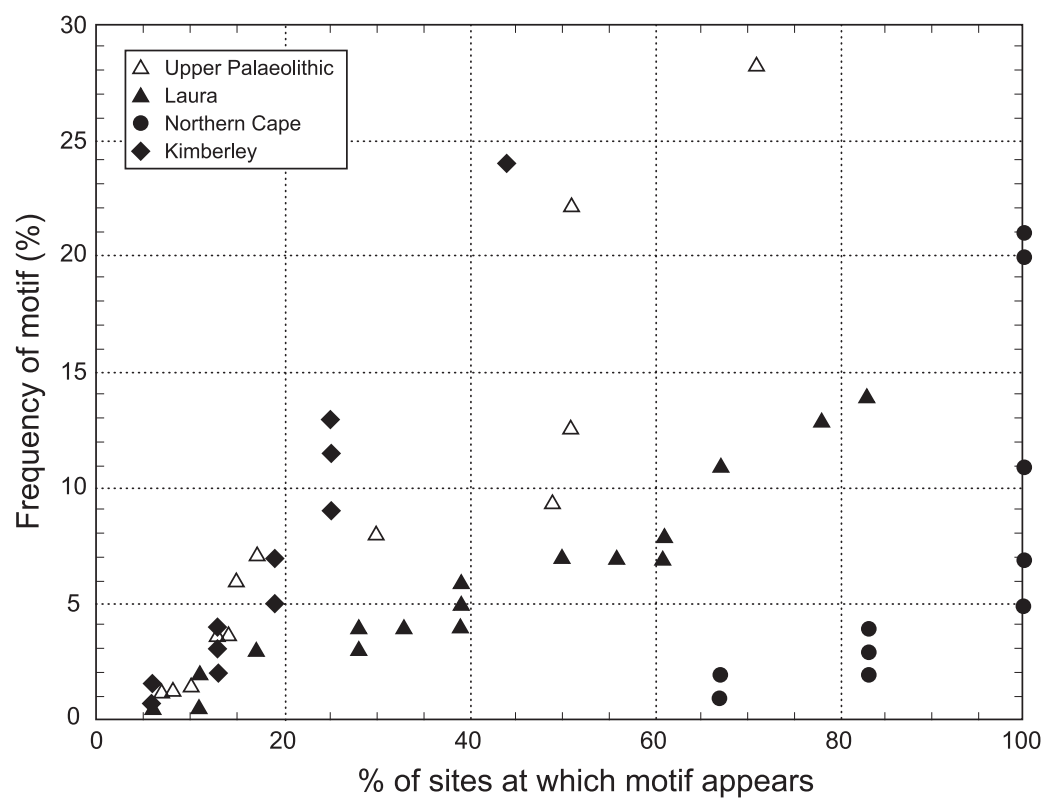

Figure 2. Initial comparison of motif frequency in whole samples and between sites within samples.

representative of the totemic scenario, as there is both good ethnography and good documentation on site-by-site motif frequencies (Fig. 3), based partly on Layton's own fieldwork but augmented by data in Schulz (1956). As no site-by-site breakdown for the frequency of motifs in the Drakensberg was available, the shamanic scenario was represented by Deacon's 1994 data on the Northern Cape of South Africa, relatively close to the home of the /Xam. The secular case was represented by the art of Laura in North Queensland, for which Trezise (1971) has published good site data and which the limited ethnography (Layton 1995) suggests was predominantly secular.

Each data point in Figure 2 represents a particular animal species, coded according to the assemblage to which it belongs. The figure shows that the method discriminates clearly between the three recent cases, each of which illustrates one of the permutations in the four-cell model. In the ethnographic case where animals function as clan totems (the Western Kimberleys) the curve is confined to the left side of the graph, owing to the fact that each species is present at a low proportion of sites. The most widely distributed motif, the generic category 'snake', occurs at 44 per cent of sites. At the other extreme, the curve for the probable 'shamanic' case, the Northern Cape of South Africa, falls entirely within the right half of the graph, since all species depicted occur at a high proportion of sites. The five most frequent motifs occur at all sites. The curve for motifs from the probable secular art of the Laura district of North Queensland is situated between the other two recent cases, since a large number of species is depicted and many occur at a large proportion of sites. All three curves follow the predictions of the model. The curve for the Upper Palaeolithic sample lies between those for the Western Kimberley and Laura, but is relatively far from the trajectory of shamanic art.

\section{A larger survey}

Encouraged by these results, we collected more comparative cases and a much fuller data set on the Upper Palaeolithic. The first of two further ethnographic studies is from Western Arnhem Land, Australia (data provided by Taçon). The recent rock art of Western Arnhem Land is, as noted above, another example of 'secular' art. Figures depicted with so-called 'X-ray' detail, i.e. realistic rendering of internal organs and tissues (Fig. 4), are identified by local artists as records of foraging, or 'just meat' (Taylor 1996, 17-20). Taçon's Aboriginal instructors showed him how a dozen different species of fish are carefully depicted with numerous anatomical details (Taçon 1988), along with other species including lizards and turtles. A parallel tradition of representing animals as transformations of totemic ancestors is practised on bark painting, in which the internal organs are replaced by geometric cross-hatching (Taylor 1996, 118ff.). The second ethnographic case is the Stein River, British Columbia. This small area on the Columbia Plateau has the benefit of a long period of ethnographic documentation, starting with James Teit (1918), who advised and guided Boas's 


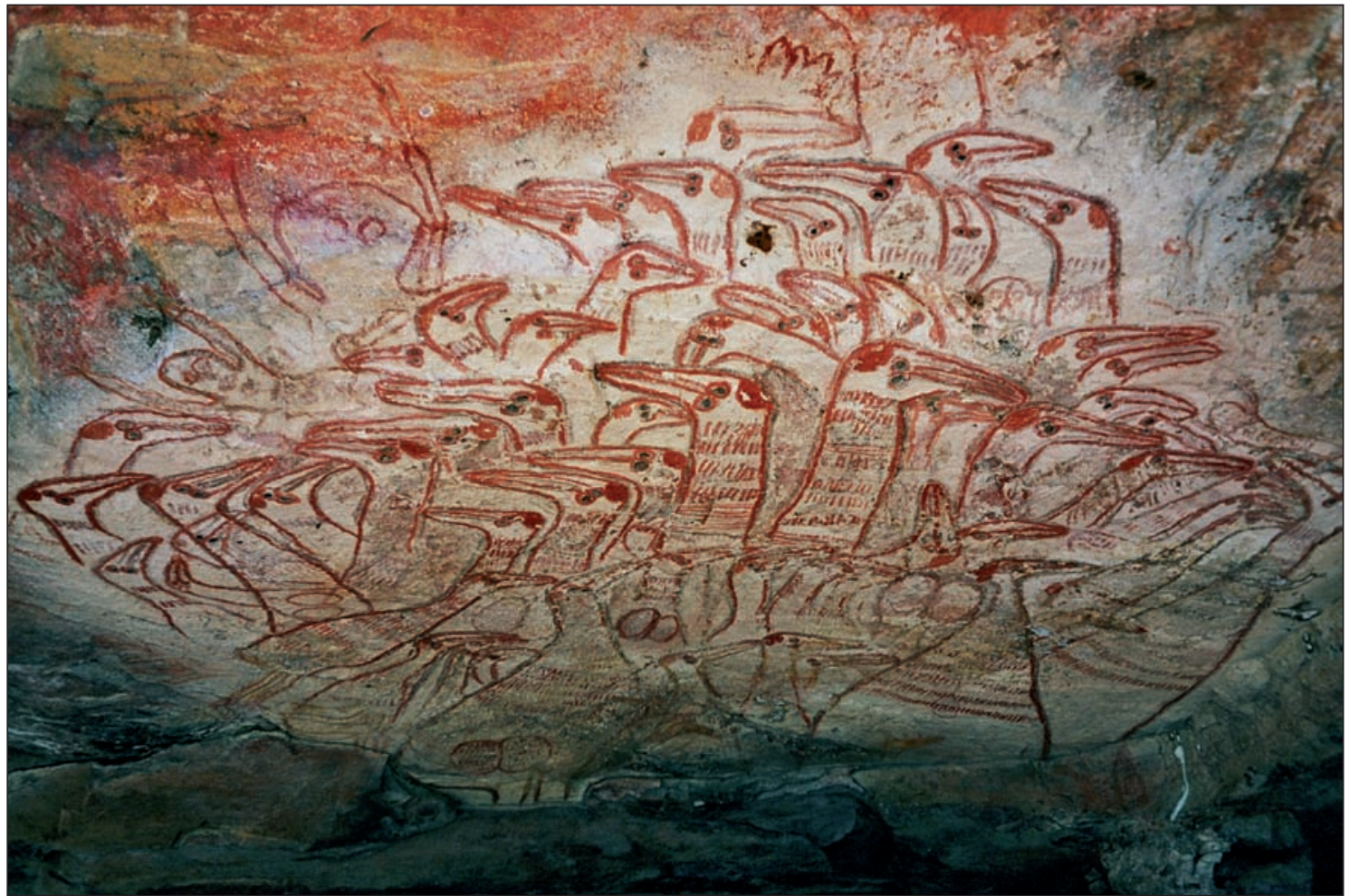

Figure 3. Brolgas (Grus rubicunda) or 'Australian cranes', Hann River, Kimberley, Australia. (Photograph: Michael Rainsbury.)

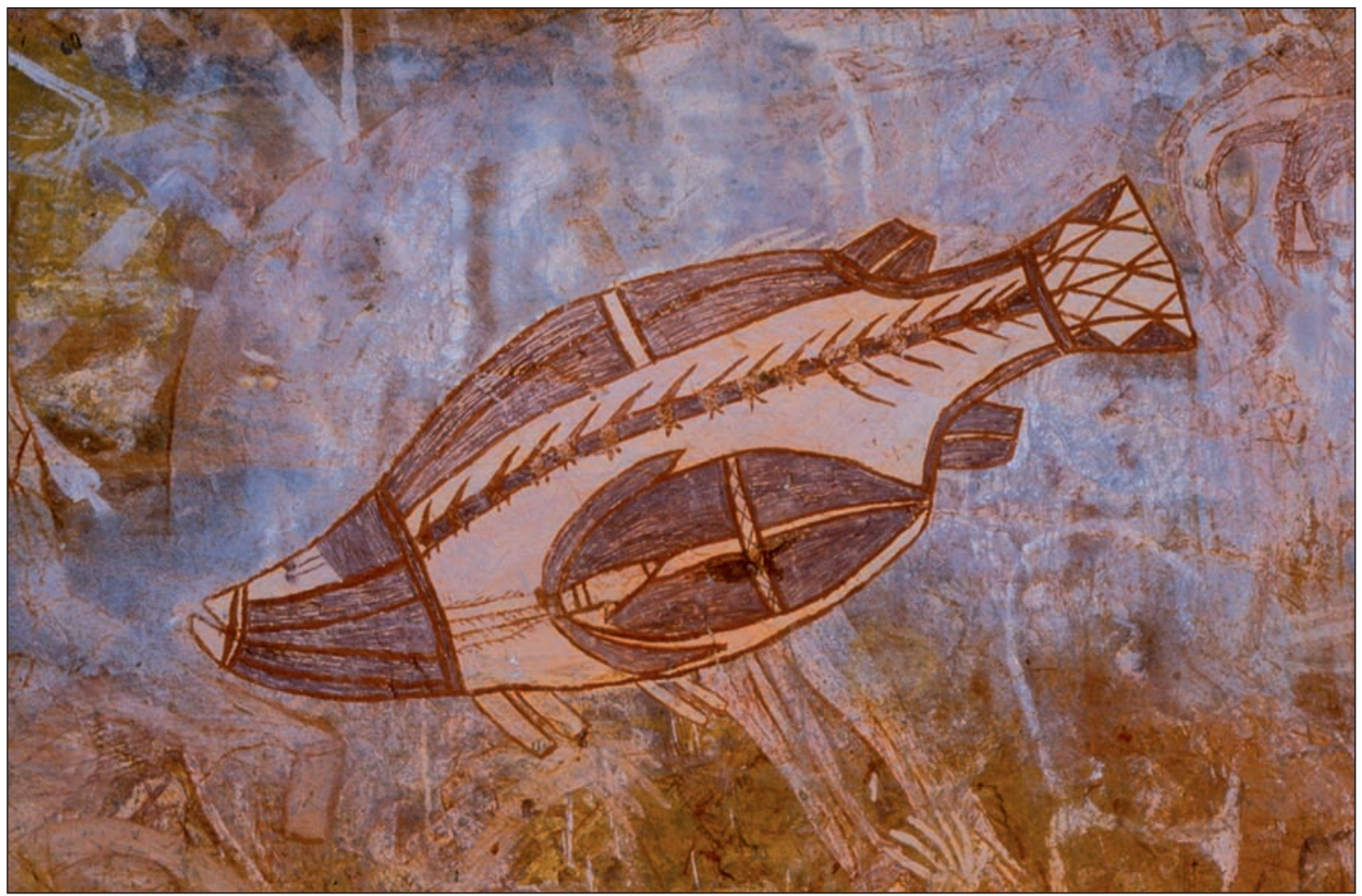

Figure 4. Barramundi (Lates calcarifer), Arnhem Land, Australia, 'X-ray' period. (Photograph: Paul Taçon.) 


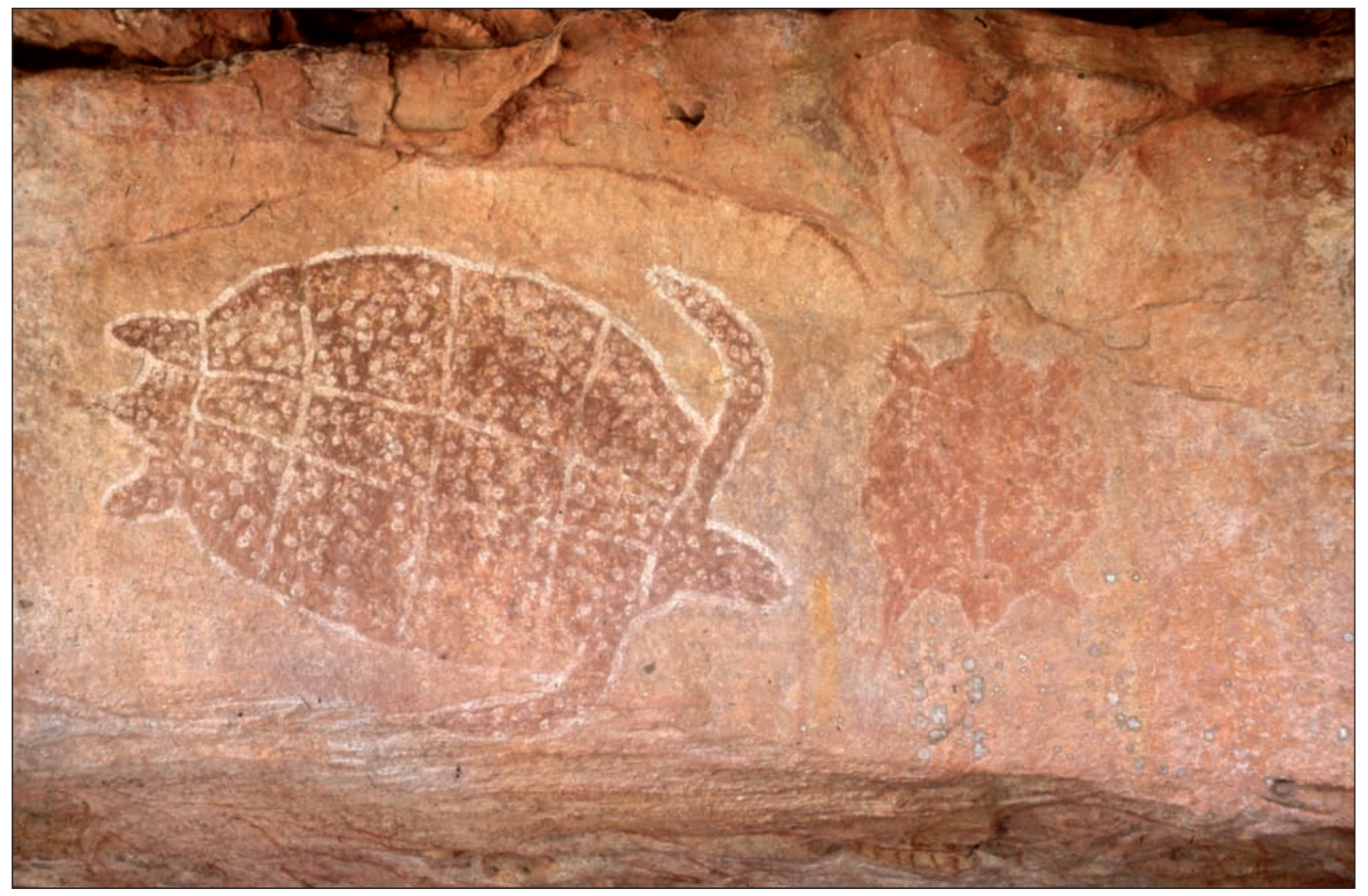

Figure 5. Turtles, Laura, North Queensland, Australia. (Photograph: Robert Layton.)

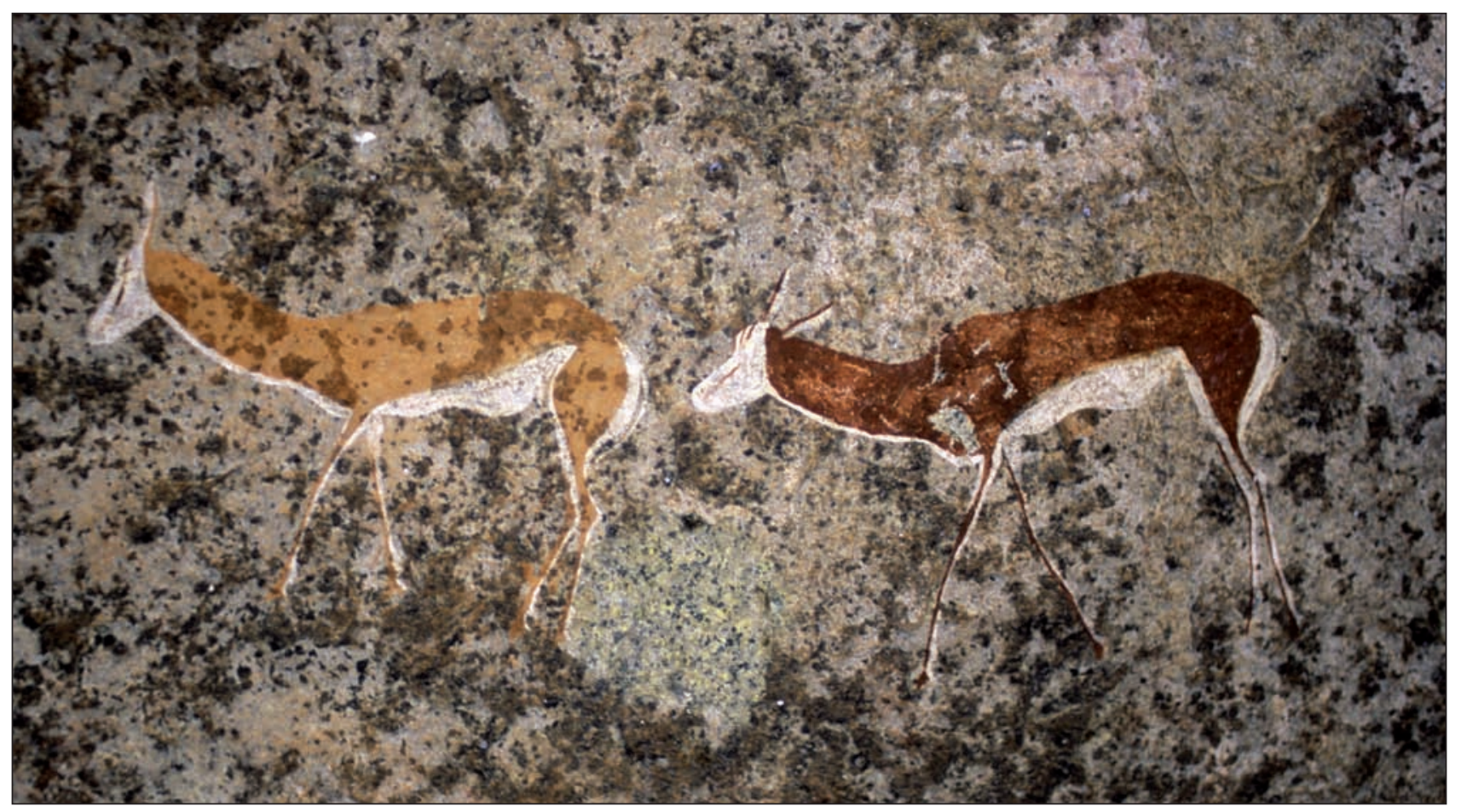

Figure 6. Springbok (Antidorcas marsupialis), Daureb/Brandberg, Namibia. (Photograph: Tilman Lenssen-Erz.) 


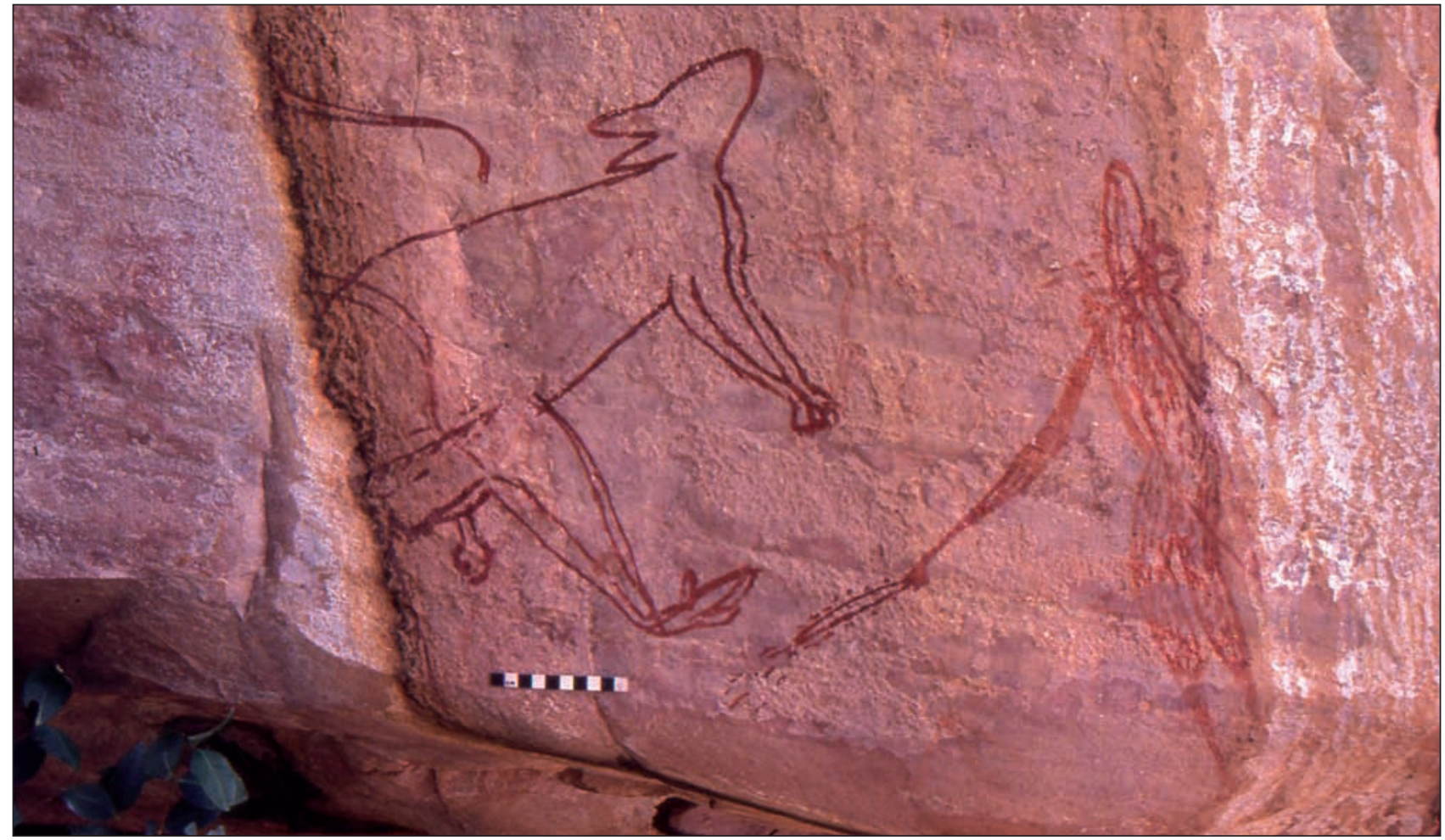

Figure 7. Macropod, Arnhem Land, Australia, Dynamic art period. (Photograph: Paul Taçon.)

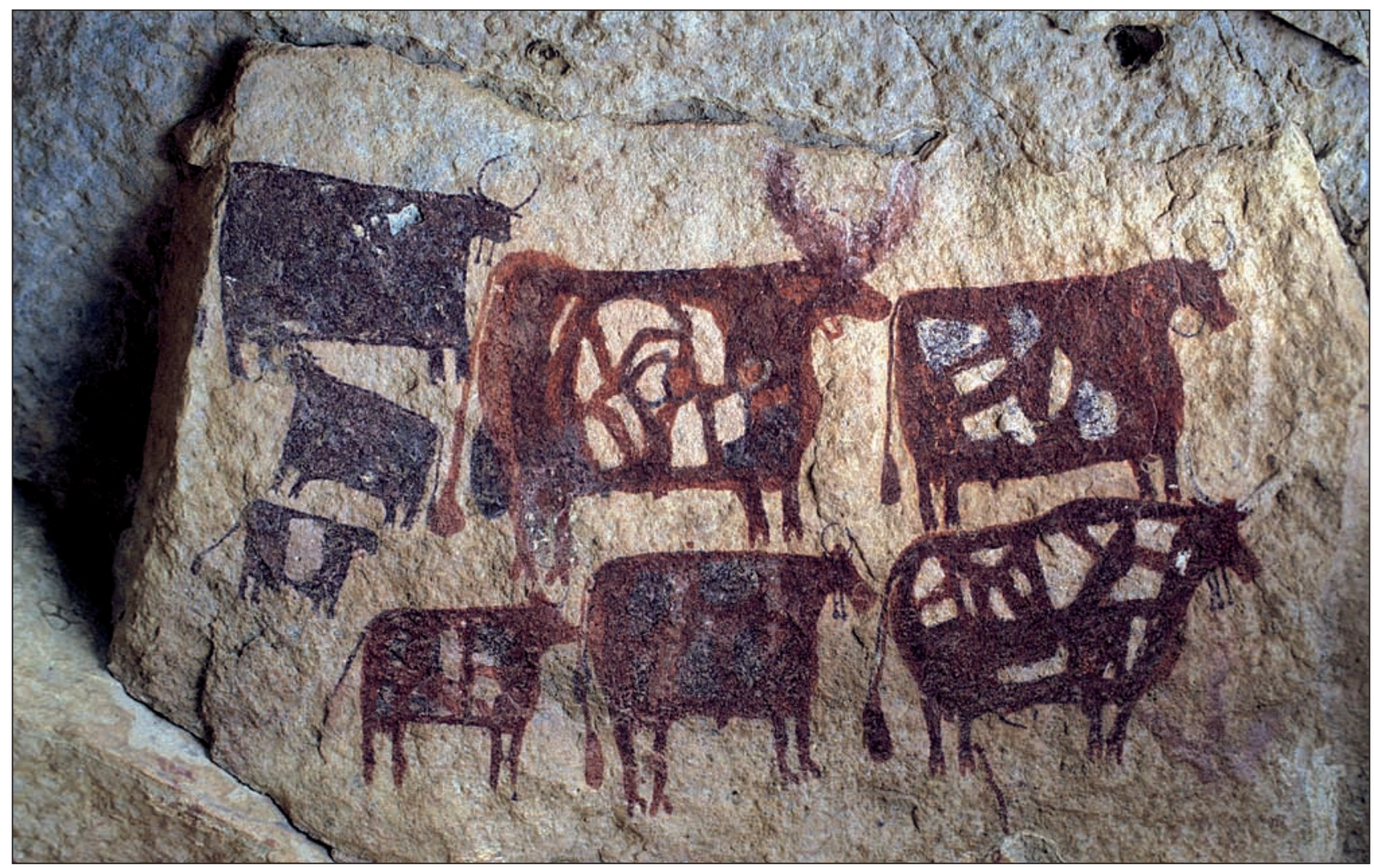

Figure 8. Cattle, Ennedi, Chad. (Photograph: Tilman Lenssen-Erz.) 


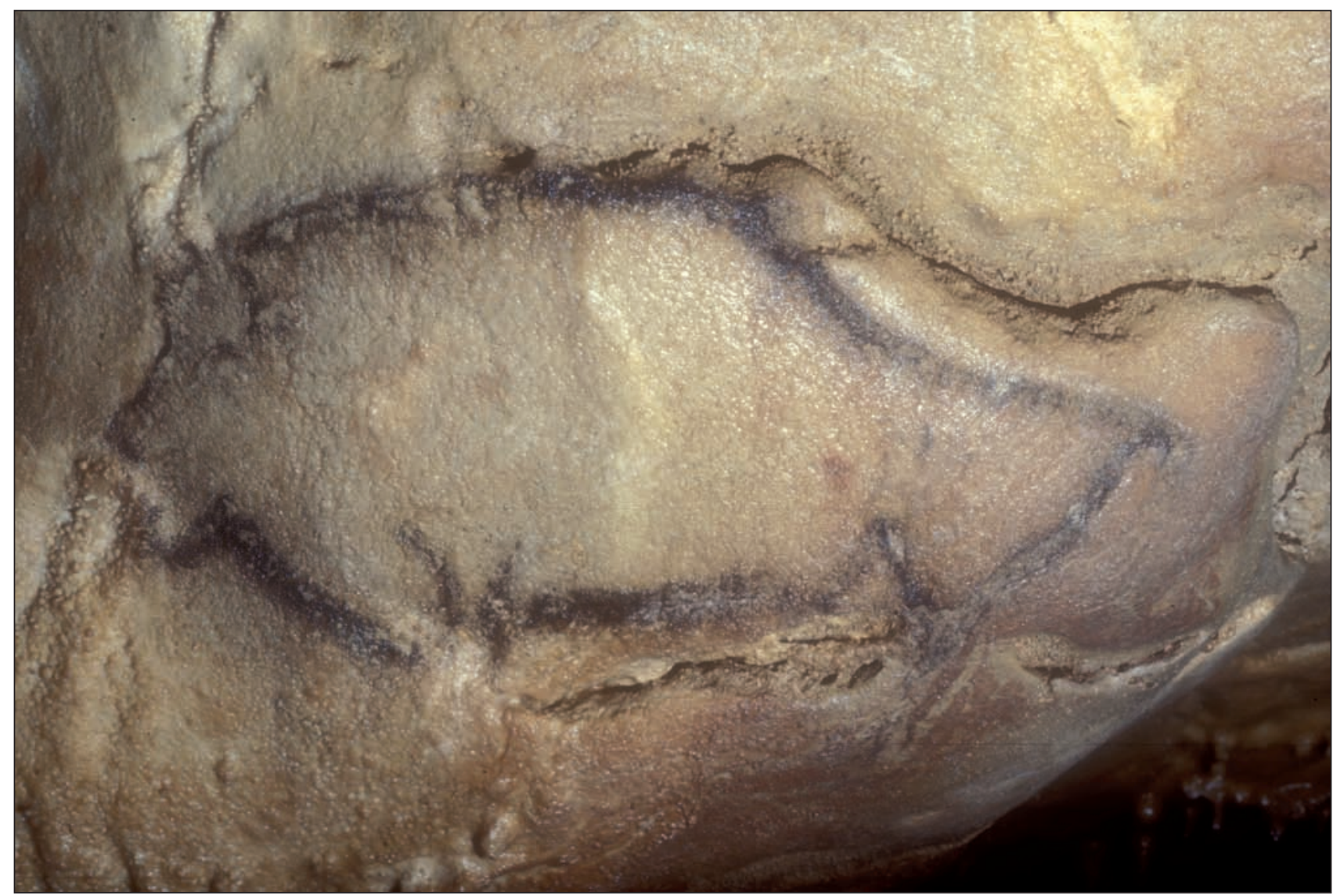

Figure 9. Bison, Portel, France, Upper Palaeolithic period. (Photograph: Georges Sauvet.)

Jessup Expedition, and extending to information provided by Annie York between 1989 and 1991 (York et al. 1993), which show that rock art was associated both with the adolescent vision quest, and the activities of professional shamans.

The Upper Palaeolithic data have been greatly increased using data collected by Sauvet and Wlodarczyk. These data have been divided into regional sub-sets that allow a spatial and diachronic analysis. Sauvet \& Wlodarczyk (2000-01) explain why they consider it safe to distinguish only two time periods; an 'archaic' period extending from the Aurignacian to the early Magdalenian, and a later period covering the Middle and Upper Magdalenian. Available C14 dates locate this temporal division at around 15,000 вр. The two periods correspond approximately to the phases that Leroi-Gourhan (1965) called Style II and Style III on one hand, and Style IV on the other.

Additional archaeological cases were provided by Ndedema Gorge, a small valley in the north of the Drakensberg Mountains of South Africa fully recorded by Pager (1971), the High Brandberg in Namibia (Fig. 6), also exhaustively recorded by Pager (1989 to 2000), the ancient 'Dynamic' rock art of Arnhem Land (Fig. 7), and the art of Ennedi, Chad (Fig. 8). Lenssen-Erz (2001) and Richter (1991) consider that the art of the High Brandberg (Daureb in the indigenous Khoekhoegowab language), Namibia, emerged from a largely secular context where springbok, the dominant motif, may have been emblematic of abundance in and after the rainy season. Pager's detailed records allowed us to distinguish six very similar sub regions in the Daureb/High Brandberg. The Dynamic Art of Arnhem land preceded the so-called ' $X$-ray' tradition. The absence of marine and coastal subjects, and the presence of boomerangs, which are now only used to the south of Arnhem Land, have been taken by Chaloupka (1993), Lewis (1988) and other archaeologists as evidence that Dynamic art was painted during a period of aridity, when Arnhem Land was far from the north coast of Australia, probably during the last glaciation. Chaloupka, Lewis and Taçon \& Chippindale (2008, 81), link the origin of ' $X$-ray' art to the formation of extensive coastal wetlands over the past 1500 years. The rock art of Ennedi (Fig. 8), a mountainous region in the northeast of Chad, is our only case not created 


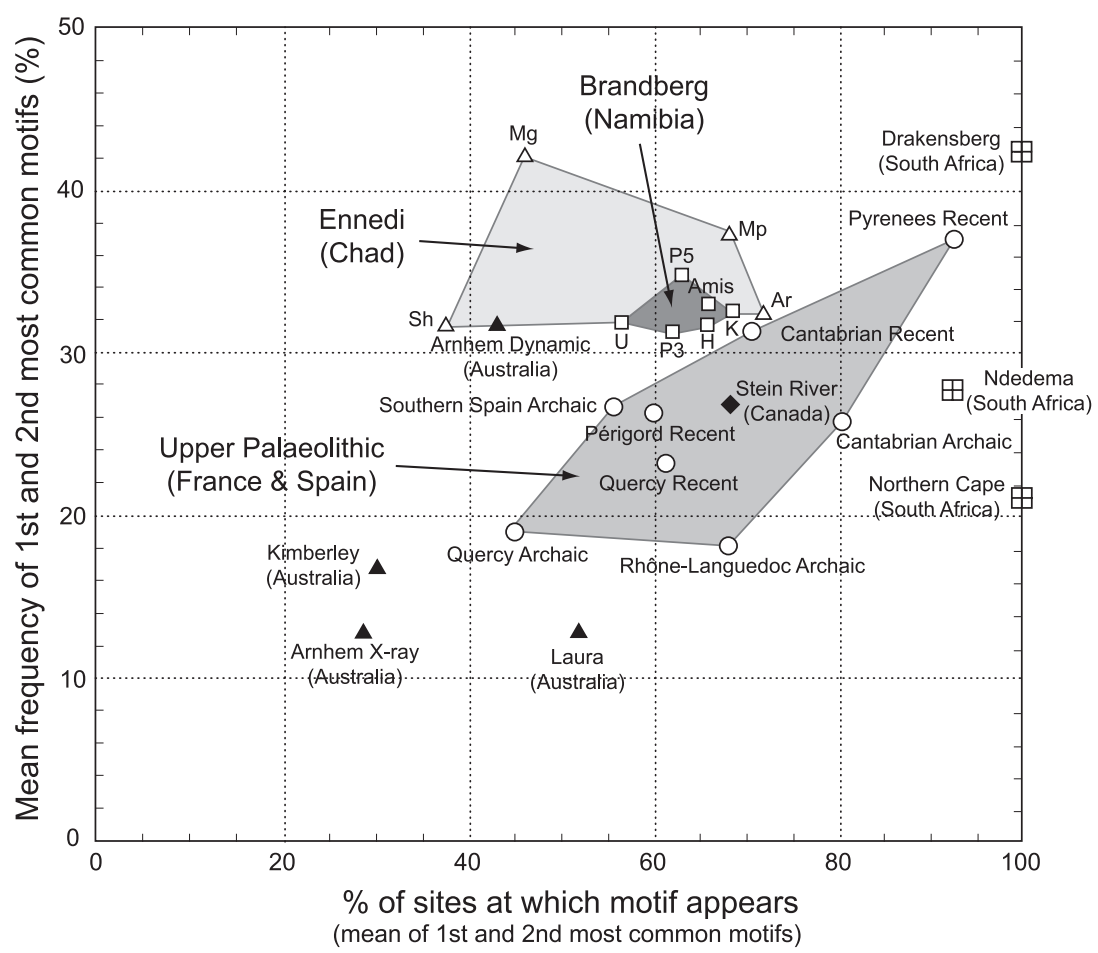

Figure 10. Enlarged survey of ethnographic and archaeological case studies. Open triangles correspond to site clusters in the Ennedi region: $\mathrm{Mp}=$ Mornou paintings, $\mathrm{Mg}=$ Mornou engravings (both northeast Ennedi), Sh=Shekitiye (central south Ennedi), Ar=Archei (west Ennedi). Open squares correspond to sub-regions in the Brandberg: Amis = Amis Gorge, $H=$ Hungorob; $K=$ Karoab; P3 = Southern Gorges; P5 = Northwestern Gorges; $U=U$ Umuab.

by hunter-gatherers. The rock art is characterized by a very strong focus on domestic cattle, which are present at practically all sites. It is likely that the art is an expression of cattle-centred behaviour and ideology analogous to the 'cattle complex' defined by Herskovits (1926), where possession of cattle is of far more than simple economic value. This complex has been extensively documented by ethnographers from Evans-Pritchard (1940) onwards, among the Nilotic cattle herders of East Africa. The art of Ennedi may also have a strong aesthetic component, as Coote (1992) showed in his study of the aesthetics of cattle coat colour among Nilotic peoples today.

Unfortunately, we found it impossible to plot the entire data set for each case on a single graph. We experimented by plotting only the most frequent motif, but found its characteristics could be skewed by a single, atypical site and eventually decided to compromise by plotting each case with a point representing the mean distribution of the two most frequent species (Fig. 10).

Figure 10 shows that the case of ' $X$-ray' art from Arnhem Land sits close to the other ethnographic case of secular art, Laura. The plot for Western Kimberley totemic art also lies low on the graph, owing to the fact that even the most common animal motifs have a low frequency. While the two commonest animal species occur at a lower proportion of sites in the Western Kimberley than at Laura (corresponding to the model's predictions), the two commonest animal species are no more widely distributed in Western Arnhem Land than they are in the Kimberley (against the model's predictions).

The distribution pattern for animal motifs during the Upper Palaeolithic varied in both time and place, but the field of variation represented by the larger Upper Palaeolithic samples sits tantalizingly between most of the ethnographic cases. During the 'archaic' phase of Palaeolithic art the Rhône-Languedoc and Quercy regions approach situations A and B (i.e. no single motif dominates, as in 'totemic' or 'secular art'), whereas the Iberian Peninsula (Andalucia and Cantabria) and Périgord tend rather to situation $C$ ('shamanic art'), due to the heavy predominance of a single motif. The dominant species in Spain is red deer (especially female), in Périgord the horse. At the start of the Middle Magdalenian there seems to have been a significant cultural convergence between Cantabria and the Pyrenees, in which the structure of the rock art conforms increasingly closely to situation C. Now 
they share the same pre-eminent motif: bison (Fig. 9). Périgord appears at this time to be marginalized, but this is due to an increase in the number of mammoth at a few sites - the 'Rouffignac effect' that we discuss below. Were it not for the huge numbers of mammoth at these sites, horse and bison would be the dominant motifs as they are in the other regions, and the position of Périgord in Figure 10 would lie closer to those of Cantabria and the Pyrenees. The only direct hit, so to speak, from the ethnography is the case of Stein River. Interesting as this is, we caution that the Stein River covers too small an area to guarantee a regionally representative sample.

The other three archaeological case studies (Arnhem Land Dynamic art, the Daureb/High Brandberg, and the pastoralist art of Ennedi) all lie in the upper half of the graph, beyond the range of the Upper Palaeolithic cases and even further from the ethnographic ones.

The overall outcome of this comparative exercise is to show that Upper Palaeolithic rock-art traditions have no close modern parallel, other than perhaps, the Stein River Valley, and generally display unique configurations in the distribution of animal motifs within and between sites. On the other hand, an interesting trend emerges within the Upper Palaeolithic in which at least two, possibly three, of the sub-regions apparently converge on a common paradigm. While this paradigm creates an archaeological signature approaching that of South African shamanism, we note below that this is not necessarily diagnostic. The archaeological cases from Africa and Australia further extend the range of possible scenarios and highlight the danger of projecting known ethnographic cultures onto those of the distant past.

\section{A critique of the method}

There are a number of methodological and interpretive issues raised by our approach.

\section{Coding the data}

Statistics based on the frequency of motifs making up an artistic vocabulary will depend directly upon the number of motifs recognized in the analysis, yet because they lack sufficient visual information some motifs are either deliberately ambiguous or appear so to the uninformed observer. Published records of rock art rely, to some extent, on general categories such as snake, bird or fish when more specific identifications are impossible. The frequency-distribution graphs obtained if a single generic 'fish' motif is recognized in 'X-ray' art (Fig. 11a), or if individual species are
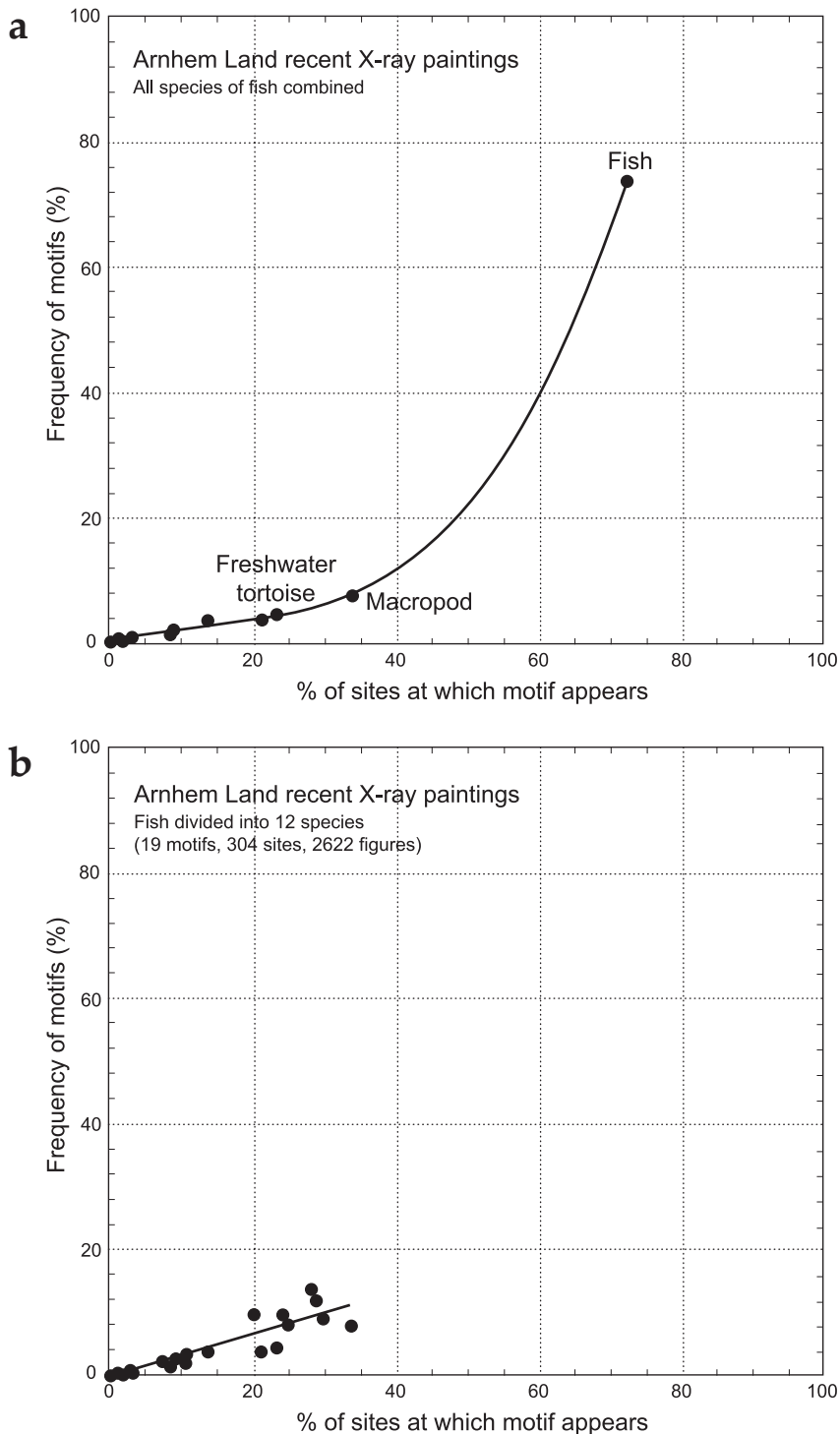

Figure 11. Distribution patterns for 'X-Ray' art, where (a) all fish grouped as 'fish', (b) individual species plotted separately.

distinguished (Fig. 11b) are very different, and would radically alter the location of the region in Figure 10, had Taçon (1988) not been instructed in the diagnostic iconography of each species. It is possible that the artists of the Dynamic Period in Arnhem Land rock art distinguished several species of macropod, but we cannot now discriminate between them and can therefore only group them as generic category.

A second difficulty is the definition of a site or a region. Is every rock shelter a separate site or can a group of adjacent rock shelters or platforms form a single site? The definition of a 'site' is not always clear in the literature. The scale of the geographical entity 


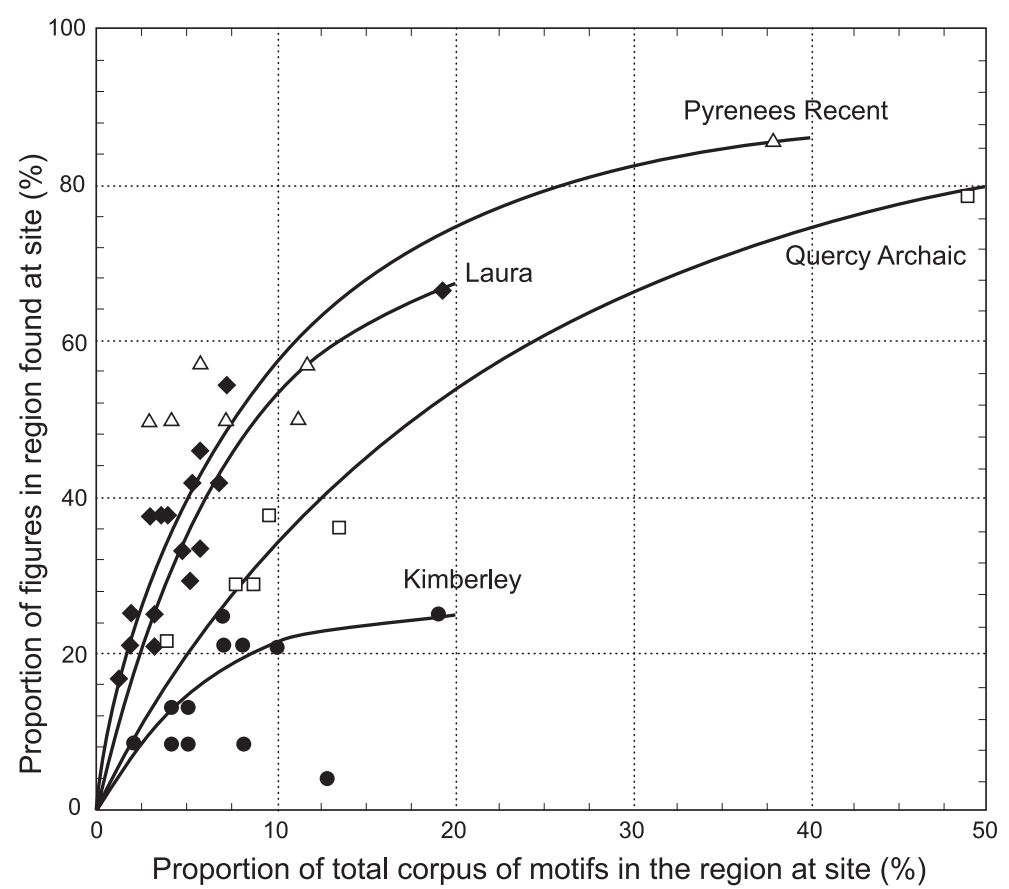

Figure 12. The effect of increased sample size on heterogeneity of motifs present.

treated as a distinct region may also cause problems. If the region is defined too broadly, its homogeneity may be questionable (e.g. Western Arnhem Land), but if the scale is too small there is a risk that the corpus will not be representative of variability within the region. In the Northern Cape region of South Africa each 'site' contains an average of 230 figures (Deacon 1994), but the Stein River sample from British Columbia consists of a mere dozen sites containing fewer than 150 figures in total. The homogeneity of Northern Cape sites may be overrated, while the Stein River may not reflect the frequency of motifs at a regional level.

Our method depends on figures accumulating for long enough to reveal the generative principles expressive of cultural context. If the motive for painting is the same at each site, and if all local groups share the iconography, one can predict that the diversity of motifs present will increase in relation to the number produced at the site (Kintigh 1989). We tested this hypothesis by measuring the diversity of motifs present at a site (expressed in terms of the proportion of the total vocabulary of motifs that are represented in the region) as a function of the size of the site (expressed as a percentage of the total number of figures in the sample that are present at that site). This test was carried out for the Western Kimberley region (totemic), the Laura region (secular) and for two regions within the Upper Palaeolithic tradition (Archaic period Quercy and Recent period Pyrenees) (Fig. 12).
In the Western Kimberley, the diversity of motifs within a site remains low and increases little with the number of figures at the site, since each site is associated with a particular totemic species. On the other hand, in both the Laura region and the Upper Palaeolithic, the diversity of motifs increases substantially with site size. This analysis distinguishes neatly between an art based on totemism and one in which all local groups depict the same motifs, but it does not allow us, in the latter case, to distinguish between alternative possible functions. One of the two regions of the Upper Palaeolithic - Archaic Quercy - is situated in the graph Figure 10 quite close to the Kimberley, but Figure 12 shows this is misleading. As the number of figures at sites increases its iconographic signature starts to conform to that of the other Franco-Cantabrian regions. This complementary analysis is thus a means to verify whether the different sub-assemblages within a single region are homogeneous or not.

The problem of multiple themes in a region's rock art Our analysis has only examined distribution patterns among animal species represented in the art. While our results tend to confirm that these patterns vary according to the cultural theme expressed through animal art, we cannot disregard the fact that many ethnographic rock-art traditions express more than one theme in the culture. 
The rock art of Laura, North Queensland, includes a number of sites where human head-dressed figures are depicted. Rosenfeld's (1982) archaeological research showed that there were two types of site at Laura. One is filled with animal paintings of numerous species, often superimposed in many layers. These tend to be found in rock shelters with substantial habitation debris. The head-dressed humans are almost always painted on otherwise empty walls in sites with little habitation debris, suggesting a ritual theme at sites to which access was restricted. In this case, it seems that the ceremonial dimension of the rock art is clearly segregated from the animal component, but the patterning of the animal component does not imply that the Aboriginal people of Laura lacked ceremonies.

The rock art of both Laura and the Western Kimberleys contains sorcery paintings. In the Kimberleys these consist of small, distorted human figures portraying the desired state of the victim. They are painted close to the ancestral totemic figures in the hope that the ancestors will punish the victim for breaking the code of social behaviour (Layton 1992, 85-6). They do not have their own pattern of animal associations. In the Laura area, sorcery paintings do impinge on the frequency of animal figures. Sorcery paintings are the only type of rock art on which Trezise was given information based on the personal experience of his Aboriginal guides. He was told that snake or catfish were sometimes painted next to the painting of a sorcery victim in the hope the animal would harm the victim (Trezise 1969, 108). Although catfish is, by a small margin, the most common species depicted in rock shelters (at 14 per cent), catfish and snake are only two of the 18 species categories identified in Laura rock art. Sorcery therefore has little effect on the overall distribution of animal motifs.

The influence of the religious significance of animal species may be more pervasive in the secular art of Western Arnhem Land. Many of the species represented with ' $X$-ray' details also appear in the sacred art represented on bark paintings. Initiation introduces young people to the sacred significance of some features or qualities of animals, particularly in species such as crocodiles and carnivorous fish. The location of recent Arnhem Land rock art may be related, therefore, to the fact that much of it is a combination of secular and totemic (see Taçon \& Chippindale 2008).

The art of the Stein River valley includes sites associated with both the adolescent vision quest and the restricted activities of shamans. The valuable early ethnography of Teit and Harlan Smith is based on interviews and site visits at a time when rock art was probably still being made, and is supported by the testimonies of Chinook people living on the Columbia River a hundred years later (Layton 2006). Boas had a high opinion of Teit's skill as an ethnographer (Joanitis 1991, 186). While the vision quest is a quest for a personal spirit guardian during a heightened form of consciousness, it is not a form of shamanism. Our Chinook instructors on the Columbia River were also adamant that entoptic forms would interfere with the clarity of vision sought, in which 'you see in your mind's eye the power in everything, even in a blade of grass' (Layton 2006, 93n). Only a few particularly skilled individuals proceed to the specialized training required of shamans. Their rock-art sites are private and may be characterized by a different frequency of motifs (see York et al. 1993, 114; Layton 2006, 89), but access to, and knowledge of, such sites is restricted. Shamanism and totemism co-exist on the Northwest Coast. Daly (in York et al. 1993, xvii) reports that as one approaches the coast the possession of a special body of knowledge by each family becomes more formalized. We would welcome a statistical comparison of the distribution of animal motifs in rock art across the Columbia Plateau and on the Northwest Coast if such data are available.

The extent to which South African rock art is exclusively concerned with trance experience has long been debated among South African researchers. It seems likely that at least some of the art relates to other aspects of San culture (Guenther 1994; Parkington \& Manhire 1997). Dowson (2007) has recently advocated calling a truce in this debate. He argues that the Cartesian distinction Western researchers make between the mundane action of hunting and the trance activities of curers obscures the sense that hunter-gatherers have of hunting and gathering as a dialogue between sentient humans and sentient non-human beings, including animals. Povinalli (1993) has made the same point with reference to Australian hunter-gatherers. Important as this insight is, many hunter-gatherer cultures have techniques, such as the use of particular styles, locations or occasions, for foregrounding particular contexts such as the ritual versus the everyday. Among the Kwakiutl, for example, shamanic experiences were associated with the winter secret societies (Boas 1996), while in Australia totemic ceremonies are performed at restricted locations.

\section{How predictive is our model?}

This article began by exploring the archaeological signatures of totemic, shamanic and secular art because 
these were, historically, the three most favoured hypotheses for the cultural context of Upper Palaeolithic cave art. However, while they are exemplars of the three possible configurations A, B and C identified in Figure 1, they may not be the only contexts that would generate the three observed distribution patterns.

Hunter-gatherers typically rely on a wide range of animal and plant foods and one might reasonably predict that, at least within a single ecological zone, a similarly wide range of animals will figure in the secular or quotidian art of neighbouring bands where no species evokes particular social significance, but it is unlikely that any rock, or other art tradition located in cell B will be devoid of symbolism (see Layton 2000, 170). The diagnostic quality is that no image has been appropriated by a particular local group, nor has any species been singled out for overriding attention. To take an example far removed from rock art, Chinese embroidery draws on a national tradition in which a variety of flowers express wishes for good luck, prosperity and many children. All these motifs are available to any needlewoman and can be seen in villages across many parts of China (Williams 1976).

Shamanism is clearly not the only religious context in which a few animal species might be favoured by all artists, and which would therefore be positioned in cell C. To researchers whose principle ethnographic contact with religion is Christianity, the case of the lamb will come to mind. If any researcher has data on a rock-art tradition associated with a monotheistic religion, we would welcome the results of an analysis of motif frequency and distribution. The pre-eminence of bison in the Magdalenian art of the Pyrenees is clearly compatible with any religion in which the bison played a pre-eminent role. Nor does there seem to be a necessary reason why art associated with shamanism should fall into cell C. Other cases can be found in the ethnography where shamanism is associated with a pre-eminent species, such as the jaguar in lowland South America (Campbell 1989), or the bear in Siberia (Jordan 2003). Marshall (1969), on the other hand, documented rapid changes in the fashionable trance rituals of the Kalahari, each associated with a different species, as does Tsuru (1988) among the Baka of Central Africa. The predominance of a single species is not a necessary condition for shamanic rock art, especially if a long enough period is under consideration. Moreover, the case of the herder rock art of the Ennedi demonstrates that the all-embracing esteem of a certain species, without implying trance as a ritual medium, may generate patterns of art production that fit into cell $\mathrm{C}$ and thus superficially compare closely with presumable shamanic art.
Among more complex societies there may be a variety of motives for identifying different sites in a culturally-constructed geography with different animal emblems. In the type of small-scale, egalitarian, clan-based societies discussed in this article, however, the association of a type A distribution pattern with totemism seems more secure. It follows, almost by definition, that the association of different species with different local groups is a form of totemism. Two case studies illustrate the potential of rock art to elucidate the origin of totemic traditions in such societies. Olsen (1989) used the evidence of the spatial distribution of art motifs to trace the origin of the type of clan totemism practised today by Hopi and Zuni clans, to their predecessors in the Anasazi farming culture that emerged around AD 500. Portable Anasazi objects tended to carry geometric designs, while fixed locations such as rock walls, boulders and kiva walls bore animal and human representations. Thirty-eight per cent of the Anasazi vocabulary of animal motifs were identical in form to modern clan emblems. Since they were non-randomly distributed in the landscape, Anasazi art provides evidence for the antiquity of the clan system and its expression in rock art.

In Australia, the development of the 'small tool' tradition appears to be associated with a reconfiguration of relationships between people and the landscape. The ancient (pre-5000 вр) core tool and scraper stone tool tradition can be characterized as an expedient stone technology. Gould (1969) and Hayden (1979), for instance, observed choppers similar to ancient core tools in use in central Australia. They noted that such choppers are sometimes made when needed to fell trees or butcher kangaroo meat, and then left at the site. However, the more recently added small tool tradition is a curated technology. Such tools are mounted on wooden shafts for future use. Excavation of camp sites associated with the small tool tradition shows that stone tools were manufactured in camp and worn out or broken tools were discarded on return to camp (see review in Flood 1995, 221ff.). During the same period (c. 6000-4000 вр), the ancient dynamic style of rock painting in western Arnhem Land is replaced (or supplemented) by a new style whose themes include composite 'Rainbow Serpent' figures (Lewis 1988, 15-17). Lewis makes the interesting suggestion that composite Rainbow Serpent paintings are symptomatic of new, regional religious cults stimulated by rising post-glacial sea-levels (Lewis 1988, 39, 109; cf. Taçon et al. 1996). Indirect evidence suggests the totemic, Wandjina style of rock art in the Kimberleys is at least 3000 years old, since the earlier styles do not depict the use of stone-tipped spears 
and Kimberley stone spear points, characteristic of the small tool tradition, are thought to appear at about 3000 вр (see Welch 1990, 123; Crawford 1968, 89-90; Crawford 1977, 358). It is therefore possible that clan totemism crystallized in parts of Australia during the reconfiguration of social relationships associated with the small tool tradition.

\section{Conclusion}

Although we have used the three dominant hypotheses for the cultural context that generated the production of Upper Palaeolithic rock art to set the parameters for our analysis, once the categorical distinctions of Figure 1 are replaced by the numerical axes of Figures 2 and 10 , it becomes possible to plot the location of different rock-art traditions in a two dimensional space where ethnographic and archaeological case studies are put on the same footing. Each, as a possible cultural world, can occupy a unique position in that space. This is particularly demonstrated by the cases of Ennedi and the Daureb/High Brandberg, which lie far from any of the ethnographic cases. One of the unexpected outcomes of plotting Figure 10 is the range of variation in time and space revealed within the Upper Palaeolithic, which might otherwise have been obscured by the remarkable uniformity in the style of the animal art during the 20,000 years from Chauvet to Niaux. While the failure of the ethnographic cases which we have available, other than perhaps the Columbia Plateau, to match the Upper Palaeolithic closely is disappointing, it is not entirely surprising to find that the cultural context of Upper Palaeolithic animal art has little or no exact modern parallel. This is a useful corrective to the slavish application of ethnographic models, but it does suggest distribution patterns in the art of the Columbia Plateau (within which the Stein River is situated) deserves further analysis.

While our analysis allows us to identify totemism as the least probable of cultural contexts for the animal art of the Upper Palaeolithic, we have noted Olsen's (1989) and Hartley's (1992) productive use of similar methods and shown how the method can be used in Australia and the American Southwest to date the probable emergence of recent totemic systems from less well understood precursors. We hope other researchers will find the method sufficiently interesting to apply it to other recent and ancient bodies of rock art and have noted two cases where we believe the collection and analysis of further data would particularly help to take our approach further.

In summary, the structural parameters expressing the frequency of motifs in a region and the distribution of these motifs between sites within the region provide important lines of evidence pointing to the cultural context of rock art in small-scale societies. If the scheme that emerges from the above discussion is more complex than that originally suggested by Layton (2000), it still enables us to test alternative hypotheses. Even if we abandon the idea that there is a direct and unambiguous relationship between the frequency and distribution of motifs and totemic organization or shamanic practices, the three distribution patterns identified by our cells $\mathrm{A}$, $B$ and $C$ are likely to be generated by the use of rock art in different contexts. The analysis of rock art in these structural terms reveals similarities between historically unrelated rock art traditions and helps us to plot continuity or change in cultural traditions over hundreds or thousands of years.

\section{Acknowledgements}

This article is dedicated to the memory of Peter Ucko and Andrée Rosenfeld: two inspirational leaders in rock-art research. The research was partly conducted within the framework of the Emergence et fonction des systèmes sémiologiques dans les groupes humains du Paléolithique supérieur which was funded by the CNRS programme Origine de l'Homme, du Langage et des Langues.

\section{Note}

The data from which Figure 2 is constructed are published in Layton 2000. The data from which Figure 10 is constructed are published in Sauvet et al. 2006.

Georges Sauvet Centre de Recherche et d'Etude de l'Art Préhistorique UTAH (UMR 5608) Toulouse France

Email: georges.sauvet@orange.fr

$$
\begin{array}{r}
\text { Robert Layton } \\
\text { Department of Anthropology } \\
\text { Durham University } \\
\text { Dawson Building } \\
\text { South Road } \\
\text { Durham } \\
\text { DH1 3LE } \\
\text { UK }
\end{array}
$$

Email:r.h.layton@durham.ac.uk:

Tilman Lenssen-Erz African Research Unit Institute of Prehistoric Archaeology 
University of Cologne

Jennerstr. 8

50823 Cologne

Germany

Email:lenssen.erz@uni-koeln.de

Paul Taçon

School of Humanities

Gold Coast Campus

Griffith University

Queensland 4222

Australia

Email:p.tacon@griffith.edu.au

André Wlodarczyk

Centre de Linguistique théorique et appliqué Maison de la Recherche (CELTA - EA 3553)

Université de Paris-Sorbonne (Paris 4)

28, rue Serpente

75006 Paris

France

Email: andre.wlodarczyk@paris-sorbonne.fr

\section{References}

Bahn, P., 1991. Where's the beef? The myth of hunting magic in Palaeolithic art, in Rock Art and Prehistory, eds. P. Bahn \& A. Rosenfeld. Oxford: Oxbow, 1-13.

Barnard, A., 1992. Hunters and Herders of Southern Africa. Cambridge: Cambridge University Press.

Beaune, S. de, 1998. Chamanisme et préhistoire: un feuilleton à épisodes. L'Homme 147, 203-19.

Bleek, D.F., 1935. Beliefs and customs of the /Xam bushmen, part VII: Sorcerors. Bantu Studies 9, 1-47.

Bleek, D.F., 1936. Beliefs and customs of the /Xam bushmen, part VIII: More about sorcerors. Bantu Studies 10, 131-62.

Campbell, A., 1989. To Square with Genesis: Causal Statements and Shamanic Ideas in Wayapi. Edinburgh: Edinburgh University Press.

Cartailhac, E. \& H. Breuil, 1906. La Caverne d'Altamira à Santillana, près Santander (Espagne). Monaco: Imprimerie de Monaco.

Chaloupka, G., 1993. Journey in Time: the World's Longest Continuing Art Tradition. Chatswood (NSW): Reed.

Clottes, J. \& J.D. Lewis-Williams, 1996. Les Chamanes de la Préhistoire: Transe et Magie dans les Grottes Ornées. Paris: Éditions Seuil.

Coote, J., 1992. 'Marvels of everyday vision': the anthropology of aesthetics and the cattle-keeping Nilotes, in Anthropology, Art and Aesthetics, eds. J. Coote \& A. Shelton. Oxford: Oxford University Press, 245-73.

Crawford, I., 1968. The Art of the Wandjina. Oxford: Oxford University Press.

Crawford, I., 1977. The relationship of Bradshaw and Wandjina art in northwest Kimberley, in Form in Indigenous
Art, ed. P.J. Ucko. Canberra: Australian Institute of Aboriginal Studies, 357-69.

Deacon, J., 1994. Rock engravings and the folklore of Bleek and Lloyd's /Xam San informants, in Contested Images: Diversity in Southern African Rock Art Research, eds. T. Dowson \& D. Lewis-Williams. Johannesburg: Witwatersrand University Press, 237-56.

Dowson, T., 2007. Debating shamanism in Southern African rock art: time to move on. South African Archaeological Bulletin 62, 49-61.

Eliade, M., 1972. Shamanism: Archaic Techniques of Ecstasy. London: Routledge.

Evans-Pritchard, E.E., 1940. The Nuer. Oxford: Oxford University Press.

Flood, J., 1995. Archaeology of the Dreamtime. Revised edition. Glasgow: Collins.

Gould, R.A., 1969. Yiwara: Foragers of the Australian Desert. Sydney: Harper-Collins.

Guenther, M., 1994. The relationship of bushman art to ritual and folklore, in Contested Images: Diversity in Southern African Rock Art Research, eds. T. Dowson \& D. Lewis-Williams. Johannesburg: Witwatersrand University Press, 257-73.

Hartley, R.J., 1992. Rock Art on the Northern Colorado Plateau. Aldershot: Avebury.

Hayden, B., 1979. Palaeolithic Reflections: Lithic Technology and Ethnographic Excavations among the Australian Aborigines. Canberra: Australian Institute of Aboriginal Studies.

Helvenston, P. \& P. Bahn, 2005. Waking the Trance Fixed. Louisville (KY): Wasteland Press.

Herskovits, M.J., 1926. The cattle complex in East Africa. American Anthropologist 28, 230-72.

Hultkrantz, A., 1989. The place of shamanism in the history of religions, in Shamanism: Past and Present, eds. M. Hoppál \& O.J. von Sadovszky. Los Angeles (LA): Fullerton, 43-51.

Joanitis, A., 1991. From the Land of the Totem Poles. New York (NY): American Museum of Natural History.

Jordan, P., 2003. Material Culture and Sacred Landscape: the Anthropology of the Siberian Khanty. Walnut Creek (CA): Altamira.

Kintigh, K., 1989. Sample size, significance, and measures of diversity, in Quantifying Diversity in Archaeology, eds. R.D. Leonard \& G.T. Jones. Cambridge: Cambridge University Press, 25-36.

Kirchner, H., 1952. Ein archäologischer Beitrag zur Urgeschichte des Schamanismus. Anthropos 47, 244-86.

Kuhn, H., 1956. The Rock Pictures of Europe. London: Sidgwick and Jackson.

Layton, R., 1992. Australian Rock Art: a New Synthesis. Cambridge: Cambridge University Press.

Layton, R., 1995. Rereading rock art: text and discourse, in Perceiving Rock Art: Social and Political Aspects, eds. K. Helskog \& B. Olsen. Oslo: Novus forlag, 217-27.

Layton, R., 2000. Shamanism, totemism and rock art: Les chamanes de la préhistoire in the context of rock art research. Cambridge Archaeological Journal 10(1), 169-86. 
Layton, R., 2006. Habitus and narratives of rock art, in Talking with the Past: the Ethnography of Rock Art, eds. J.D. Keyser, G. Poetschat \& M. Taylor. Portland (OR): The Oregon Archaeological Society, 73-99.

Lenssen-Erz, T., 2001. Gemeinschaft - Gleichheit - Mobilität. Felsbilder im Brandberg, Namibia und ihre Bedeutung. Cologne: Heinrich-Barth-Institut.

Leroi-Gourhan, A., 1965. Préhistoire de l'Art Occidental. 1st edition. Mazenod: Paris.

Lévi-Strauss, C., 1962. Totemism, trans. R. Needham. London: Merlin.

Lévi-Strauss, C., 1964. The Savage Mind. London: Weidenfeld and Nicolson.

Lewis, D., 1988. The Rock Paintings of Arnhem Land: Social, Ecological and Material Culture Change in the Post-Glacial Period. (British Archaeological Reports 145.) Oxford: BAR.

Lewis, I.M., 1971. Ecstatic Religion: an Anthropological Study of Spirit Possession and Shamanism. Harmondsworth: Penguin.

Lewis-Williams, D., 1981. Believing and Seeing: Symbolic Meanings in Southern San Rock Paintings. London: Academic Press.

Lewis-Williams, J.D. \& T.A. Dowson, 1988. The signs of all times: entoptic phenomena in Upper Paleolithic art. Current Anthropology 29, 201-45.

Marshall, L., 1969. The medicine dance of the !Kung bushmen. Africa 39, 347-81.

Mulvaney, K., 1996. What to do on a rainy day: reminiscences of Mirriuwung and Gadjerong artists. Rock Art Research 13, 3-20.

Olsen, N., 1989. Social roles of animal iconography: implications for archaeology from Hopi and Zuni ethnographic sources, in Animals into Art, ed. H. Morphy. London: Unwin, 417-39.

Pager, H., 1971. Ndedema Gorge: a Documentation of the Rock Paintings of the Ndedema Gorge. (2 vols.) Graz: Akademische Druck- und Verlagsanstalt.

Pager, H., 1989. The Rock Paintings of the Upper Brandberg, part 1: Amis Gorge. (2 vols.) Cologne: Heinrich-BarthInstitut.

Pager, H., 1993. The Rock Paintings of the Upper Brandberg, part 2: Hungorob Gorge. (2 vols.) Cologne: HeinrichBarth-Institut.

Pager, H., 1995. The Rock Paintings of the Upper Brandberg, part 3: The Southern Gorges. (2 vols.) Cologne: Heinrich-Barth-Institut.

Pager, H., 1998. The Rock Paintings of the Upper Brandberg, part 4: Umuab and Karoab Gorges. (2 vols.) Cologne: Heinrich-Barth-Institut.

Pager, H., 2000. The Rock Paintings of the Upper Brandberg, part 5: Naib Gorge (A) and the Northwest. (2 vols.) Cologne: Heinrich-Barth-Institut.

Parkington, J. \& A. Manhire, 1997. Processions and groups: human figures, ritual occasions and social categories in the rock paintings of the Western Cape, South Africa, in Beyond Art: Pleistocene Image and Symbol, eds. M. Conkey, O. Soffer, D. Stratmann \& N. Jablonski. San Franciso (CA): Memoirs of the California
Academy of Sciences 23, 301-20.

Povinalli, E.A., 1993. 'Might be something': the language of indeterminacy in Australian Aboriginal land use. Man 28, 679-704.

Reichel-Dolmatoff, G., 1978. Drug-induced optical sensations and their relationship to applied art among some Colombian Indians, in Art in Society, eds. M. Greenhalgh \& V. Megaw. London: Duckworth, 289-304.

Reinach, S., 1903. L'Art et la magie à propos des peintures et des gravures de l'Age du Renne. Anthropologie 14, 257-66.

Richter, J., 1934. Studien zur Urgeschichte Namibias. Cologne: Heinrich-Barth-Institut.

Rosenfeld, A., 1982. Style and meaning in Laura art. Mankind 13, 199-217.

Sauvet, G. \& A. Wlodarczyk, 2000-2001. L'Art pariétal, miroir des sociétés paléolithiques. Zephyrus 53-54, 215-38.

Sauvet, G., R. Layton, T. Lenssen-Erz, P. Taçon \& A. Wlodarczyk, 2006. La structure iconographique d'un art rupestre est-elle une clef pour son interprétation? Zephyrus 59, 195-208.

Schulz, A., 1956. North-west Australian rock paintings. Memoirs of the National Museum of Victoria 20, 7-57 and plates.

Spencer, B. \& F. Gillen, 1899. The Native Tribes of Central Australia. London: Macmillan.

Taçon, P.S.C., 1988. Identifying fish species in the recent rock paintings of western Arnhem Land. Rock Art Research 5, 3-15.

Taçon, P.S.C. \& C. Chippindale, 2008. Changing places: ten thousand years of north Australian rock-art transformation, in Time and Change: Archaeological and Anthropological Perspectives in the Long-Term in HunterGatherer Societies, eds. D. Papagianni, H. Maschner \& R. Layton. Oxbow Press: Oxford, 73-94.

Taçon, P.S.C., M. Wilson \& C. Chippindale, 1996. Birth of the Rainbow Serpent in Arnhem land rock art and oral history. Archaeology in Oceania 31, 103-24.

Taylor, L., 1996. Seeing the Inside. Oxford: Oxford University Press.

Teit, J., 1918. Notes on Rock Paintings in General, 1918. Unpublished manuscript, Glenbow Alberta Institute Archives.

Tilley, C., 1991. Material Culture and Text: the Art of Ambiguity. London: Routledge.

Trezise, P., 1969. Quinkan Country. Sydney: Reed.

Trezise, P., 1971. Rock Art of Southeast Cape York. Canberra: Australian Institute of Aboriginal Studies.

Tsuru, D., 1998. Diversity of ritual spirit performances among the Baka pygmies in southeastern Cameroon. African Study Monographs, Supplement 25, 47-84.

Turner, D., 1973. The rock art of Bickerton Island. Oceania 43, 286-325.

Vinnicombe, P., 1976. People of the Eland. Pietermaritzburg: University of Natal Press.

Vitebsky, P., 1995 The Shaman: Voyages of the Soul. London: Macmillan.

Welch, D., 1990. The bichrome art period in the Kimberley, 
Australia. Rock Art Research 7, 110-24.

Whitley, D., 1994. By the hunter, for the gatherer: art, social relations and subsistence change in the prehistoric Great Basin. World Archaeology 25, 356-73.

Williams, C.A.S., 1976. Outlines of Chinese Symbolism and Art Motives. 3rd edition. New York (NY): Dover.

York, A., R. Daly \& C. Arnett, 1993. They Write their Dreams on the Rock Forever. Rock Writings in the Stein River Valley of British Columbia. Vancouver: Talonbooks.

\section{Author biographies}

Georges Sauvet is Professor at the University of Provence and a specialist in Upper Palaeolithic Societies. Applying methods of data analysis to the study of cave art and portable art, he has developed structural and semiotic methods to demonstrate long-range relationships between Palaeolithic groups in southwestern Europe.

Robert Layton is Professor of Anthropology at the University of Durham (UK). His research interests include art, social change and social evolution, and indigenous rights. His publications include The Anthropology of Art (2nd edition, Cambridge University Press, 1991), and Australian Rock Art, a New Synthesis (Cambridge University Press, 1992).
Tilman Lenssen-Erz has conducted research into rock art of southern and northern Africa since 1986. He is compiler of the six-volumed catalogue series on the rock art of the Brandberg/Daureb as recorded by the late Harald Pager. Research interests focus on ecological and spatial aspects of art.

Paul Taçon FsA is Professor of Anthropology and Archaeology at Griffith University, Queensland. He has over 70 months archaeological and ethnographic field experience on four continents, and has co-edited three books (including The Archaeology of Rock-art with C. Chippindale). He has published numerous papers on art, material culture, cultural evolution, identity and contemporary Indigenous issues.

André Wlodarczyk is Professor and research director in the field of computational linguistics at the Centre for Theoretical and Applied Linguistics, Paris-Sorbonne University. With Georges Sauvet, he has published a number of papers on the structural (semiological and formal) aspects of the Palaeolithic cave art. 